\title{
LinexTester Analysis and Estimating Combining Abilities for Yield and Some Yield Components in Soybean (Glycine max L. Merrill)
}

\author{
Tadesse Ghiday*, Tizzazu $D^{1}$ \\ "Holetta Agricultural Research Center P.O.Box 31, Holetta, Ethiopia. \\ ${ }^{1}$ Pawe Agricultural Research Center, Ethiopia
}

\begin{abstract}
Combining ability is mostly used by breeders to select appropriate parental cultivars to produce the larger progeny of new combinations through their hybridization. The objectives of this research were to estimate general combining ability of parents and specific combining abilities of $F_{1}$ hybrids, to identify suitable parents and hybrids for yield and its contributing traits. In this study, $18 F_{1}$ hybrids obtained by crossing six lines (Ethiopia) with three testers (Brazil) in line $\times$ tester mating design during summer season of 2013-14 and were planted in complete randomized block design with two replications during summer season of 2014-15. Among the lines, BELESA 95 proved to be a good general combiner for number of pods per plant, grain yield per plant and pod weight. Majority of the best specific combination for different characters resulted from the crosses among the parents with high $\times$ low and low $\times$ low GCA effects. Non-additive effects were predominant for number of pods per plant and grain yield, but appreciable additive effects were observed for hundred seed weight, pod weight and primary branches. Non-additive as well as additive types of gene action are more important for soybean improvement.
\end{abstract}

Keywords: Soybean, GCA, SCA.

\section{INTRODUCTION}

In self pollinated crops like soybean (Glycine max (L.) Merrill), recombination breeding has been extensively used to develop the variability reservoir for exploitation in breeding program [1]. In a systematic breeding program, it is essential to identify the elite parents for hybridization, and superior crosses to expand the variability reservoirs for selection of superior genotypes [2]. Combining ability studies help in such endeavor [3]. In the present investigation, line $\times$ tester design with well adapted and widely grown varieties of soybean (tester) was used to obtain information on combining ability of elite lines for five characters of economic importance in soybean.

\section{MATerial AND MethodS}

Nine cultivar lines were selected on the basis of their geographical adaptation and morphological diversity. Out of them, three were testers (males), each crossed with six cultivar lines used as lines (females). All the testers (PSB2005-03, PSB2005-04 and PSB2005-06) were obtained from Brazil as introduced lines (which are currently under production in Brazil). All the six lines (GIZO, AFGAT, GISHAMA, BELESA-95, ETHIOUGOSLVIA, and WOGAYEN) are high yielding Ethiopian lines in the Southern West and Northern West parts of the country released for commercial production.

Eighteen $\mathrm{F}_{1} \mathrm{~S}$ along with nine parents were planted in complete randomized block design with two replications during summer season of 2014-15 at experimental station of Pawe Agricultural Research Center. The parents were randomized among themselves. Each replication have single row of 5 meters length at $60 \mathrm{~cm} \times 10 \mathrm{~cm}$ spacing. The mean data was recorded on ten random plants for five quantitative characters viz. number of pods per plant, grain yield per plant, hundred seed weight, pod weight and number of primary branches that was used for statistical analysis. The combining ability was done adapting Kempthorne [4] procedure. The total variance among $\mathrm{F}_{1}$ hybrids was further partitioned into variance due to lines, testers and their interaction component, which was used to 
estimated the additive and non-additive components of variance. Also, the contribution of lines, testers and their interaction towards total variability for each character was computed for assessing their relative importance according to Singh and Chaunhary [9].

\section{RESUlTS AND DiscuSSION}

\subsection{Analysis of Variance}

Analysis of variance indicated the presence of significant difference among the treatments for all the five characters studied (Table 1). The parents differed significantly for all the characters except grain yield. The testers differed significantly for number of pods per plant, grain yield and hundred seed weight. The hybrids showed significant differences only for pod weight. Further partitioning of variance among the hybrids showed that the mean square due to lines were significant for hundred seed weight and pod weight, due to testers for number of pods per plant, grain yield and hundred seed weight, and number of pods per plant in case of line $\mathrm{x}$ tester interactions (Table 1).

Table 1. Analysis of variance for five characters in soybean.

\begin{tabular}{|l|l|l|l|l|l|l|}
\hline Source of variation & d.f & $\begin{array}{l}\text { Number } \\
\text { of pods } \\
\text { per plant }\end{array}$ & $\begin{array}{l}\text { Grain } \\
\text { yield }\end{array}$ & $\begin{array}{l}\text { Hundred } \\
\text { seed weight }\end{array}$ & Pod weight & $\begin{array}{l}\text { No. of primary } \\
\text { branches }\end{array}$ \\
\hline Replication & 1 & 239 & 63.3 & 693.9 & 0.05 & 41.1 \\
\hline Treatments & 26 & $71.7^{* *}$ & $26.2^{*}$ & $127^{* *}$ & $0.04^{* *}$ & $3.3^{* *}$ \\
\hline Parents & 8 & $110.1^{* *}$ & 24.4 & $307.1^{* *}$ & $0.05^{* *}$ & $8.0^{* *}$ \\
\hline Parents vs crosses & 1 & $190.4^{* *}$ & $157.3^{* *}$ & 0.3 & 0.1 & 0.1 \\
\hline Hybrids & 17 & 50.8 & 21.9 & 55.6 & $0.03^{*}$ & 1.4 \\
\hline Lines & 5 & 59.1 & 23.1 & $83.7^{*}$ & $0.07^{* *}$ & 1.9 \\
\hline Testers & 2 & $140.4^{*}$ & $63.6^{*}$ & $208.1^{* *}$ & 0.02 & 1.1 \\
\hline Lines $\times$ testers & 10 & $35.5^{* *}$ & 16.1 & 22.5 & 0.02 & 1.1 \\
\hline error & 26 & 29.3 & 15.1 & 43.6 & 0.02 & 1.7 \\
\hline
\end{tabular}

*, **significant at $5 \%$ and $1 \%$ levels, respectively

Table 2. Proportional contribution (\%) to total variance for five characters in soybean.

\begin{tabular}{|l|l|l|l|l|l|}
\hline $\begin{array}{l}\text { Source of } \\
\text { variation }\end{array}$ & $\begin{array}{l}\text { Number of pods } \\
\text { per plant }\end{array}$ & Grain yield & $\begin{array}{l}\text { Hundred seed } \\
\text { weight }\end{array}$ & Pod weight & $\begin{array}{l}\text { No. of } \\
\text { primary } \\
\text { branches }\end{array}$ \\
\hline Lines & 35.8 & 32.5 & 46.3 & 63.7 & 43.6 \\
\hline Testers & 21.3 & 22.4 & 28.8 & 5.6 & 6.1 \\
\hline Lines $\times$ testers & 42.9 & 45.1 & 24.9 & 30.7 & 50.3 \\
\hline
\end{tabular}

This was also clearly illustrated when the proportional contribution of each character studied. Lines and their interaction with testers contributed more than $70 \%$ of the total variance for all the characters. Except for number of pods per plant (21.3\%), grain yield (22.4\%) and hundred seed weight $(28.8 \%)$, the contribution of testers was very little. The contribution of lines varied from $32.5 \%$ for grain yield to $63.7 \%$ for pod weight (Table 2).

\subsection{Variance Components}

The estimate of variance components (GCA and SCA) indicated that non-additive components were dominant for number of pods per plant and grain yield, though appreciable additive effects were noted for hundred seed weight, pod weight and primary branches (Table 3), as reported earlier by El-Hosary [5] and Kumar [7]. These observations suggest that in soybean breeding, the methodology that can exploit both the additive as well as non-additive effects would be of immense value. Diallel selective mating of Raj [6] and El-Hosary [5], which provides better opportunity for recombination, 
LinexTester Analysis and Estimating Combining Abilities for Yield and Some Yield Components in Soybean (Glycine max L. Merrill)

accumulation of desirable genes and selection would help in concentrating most of such genes in a pure line [11]. A judicious integration of the classical approach (Pedigree and Bulk) with diallel selective mating may be of great help in achieving the quantum jump in soybean improvement [2] [8] and [10].

Table 3. Estimates of variance components for five characters in soybean.

\begin{tabular}{|l|l|l|l|l|l|}
\hline $\begin{array}{l}\text { Source of } \\
\text { variation }\end{array}$ & $\begin{array}{l}\text { Number of pods per } \\
\text { plant }\end{array}$ & $\begin{array}{l}\text { Grain } \\
\text { yield }\end{array}$ & $\begin{array}{l}\text { Hundred } \\
\text { weight }\end{array}$ & $\begin{array}{l}\text { Pod } \\
\text { weight }\end{array}$ & $\begin{array}{l}\text { No. of primary } \\
\text { branches }\end{array}$ \\
\hline GCA & 0.48 & 0.18 & 1.02 & 0.0001 & 0.08 \\
\hline SCA & 3.07 & 0.47 & -0.69 & 0.0001 & -0.05 \\
\hline GCA/SCA & 0.15 & 0.38 & -1.47 & 1.000 & -1.60 \\
\hline
\end{tabular}

The estimates of GCA effects (Table 4) showed that among lines and testers, BELESA 95 was superior, as it showed positive and significant GCA effects for number of pods per plant and grain yield, beside pod weight. The lines ETHIOUGOSLAVIA and GIZO were good combiners for hundred seed weight (Table 4). None of the testers was found to be a good general combiner. Association between per se performance and GCA effects was not evident in the present study. In fact, in many cases, the lines or testers with high mean had low GCA effects, indicating the ineffectiveness of choice of parents based on per se performance for hybridization (Table 5).

Table 4. General combining ability effect of the lines and testers for five characters in soybean.

\begin{tabular}{|l|l|l|l|l|l|}
\hline Source of variation & $\begin{array}{l}\text { Number of pods } \\
\text { per plant }\end{array}$ & $\begin{array}{l}\text { Grain } \\
\text { yield }\end{array}$ & $\begin{array}{l}\text { Hundred seed } \\
\text { weight }\end{array}$ & $\begin{array}{l}\text { Pod } \\
\text { weight }\end{array}$ & $\begin{array}{l}\text { No. of primary } \\
\text { branches }\end{array}$ \\
\hline Lines & & & & & \\
\hline AFGAT & 2.47 & 0.89 & 0.57 & 0.08 & 0.41 \\
\hline WOGAYEN & 1.11 & 0.48 & 0.55 & -0.01 & 0.33 \\
\hline ETHIOUGOSLAVIA & -4.43 & -1.67 & $4.27^{*}$ & -0.03 & 0.93 \\
\hline GIZO & -0.49 & -0.64 & $6.48^{*}$ & $-0.16^{*}$ & -0.03 \\
\hline BELESA 95 & $5.89^{*}$ & $4.24^{*}$ & 2.00 & $0.11^{*}$ & -0.37 \\
\hline GISHAMA & 2.47 & 0.89 & 0.57 & 0.08 & 0.41 \\
\hline SE \pm & 2.21 & 1.59 & 2.70 & 0.05 & 0.53 \\
\hline SE(gi-gj) & 3.13 & 2.25 & 3.81 & 0.07 & 0.75 \\
\hline Testers & & & & & \\
\hline PSB2005-03 & 1.48 & 1.30 & 3.07 & -0.04 & -0.24 \\
\hline PSB2005-06 & 1.74 & 0.86 & 0.59 & 0.03 & -0.02 \\
\hline PSB2005-04 & $-3.22^{*}$ & $-2.16^{*}$ & $-3.66^{*}$ & 0.01 & 0.26 \\
\hline SE \pm & 1.28 & 0.92 & 1.56 & 0.03 & 0.30 \\
\hline SE(gi-gj) & 1.8 & 1.30 & 2.20 & 0.04 & 0.43 \\
\hline
\end{tabular}

*Significant at $5 \%$ level

Fourteen out of eighteen crosses occupied the first five ranks for five characters (Table 5). The four top ranking for grain yield proportionate to the order of number of pods per plants indicates the close association between number of pods per plant and grain yield. Eleven crosses were between low $x$ low, two crosses between high $\times$ low and only one cross involved high $\mathrm{x}$ high gca parents. The largest number of low $\times$ low and high $\times$ low gca crosses in top ranks for different characters is of great interest, as such combinations could result in desirable trans gressive segregants if the additive effects of one parent and the complementary epistatsic effects (present in the cross) act in the same direction and maximize the expression of plant attributes under selection. 
Tadesse Ghiday \& Tizzazu D

Table 5. Specific combining ability of the best five crosses based on per se performances.

\begin{tabular}{|c|c|c|c|c|c|}
\hline \multirow{2}{*}{ CHARACTER } & \multirow{2}{*}{ CROSS } & \multirow{2}{*}{ MEAN } & \multirow{2}{*}{$\begin{array}{l}\text { Sca } \\
\text { EFFECT }\end{array}$} & \multicolumn{2}{|c|}{ Gca Status of parent } \\
\hline & & & & $\mathrm{P} 1$ & $\mathrm{P} 2$ \\
\hline \multirow{5}{*}{$\begin{array}{l}\text { Number of } \\
\text { pods per plant }\end{array}$} & BELESA 95 X PSB2005-03 & 44.2 & 6.57 & High & Low \\
\hline & ETHIUGOSLAVIA X PSB2005-06 & 39.5 & 5.92 & Low & Low \\
\hline & BELESA 95 X PSB2005-06 & 37.2 & -0.69 & High & Low \\
\hline & AFGAT X PSB2005-03 & 37.2 & 2.99 & Low & Low \\
\hline & GIZO X PSB2005-06 & 34.1 & 2.59 & Low & Low \\
\hline \multirow[t]{5}{*}{ Grain yield (g) } & BELESA 95 X PSB2005-03 & 30.0 & 4.82 & High & Low \\
\hline & ETHIUGOSLAVIA X PSB2005-06 & 24.5 & 3.18 & Low & Low \\
\hline & BELESA 95 X PSB2005-06 & 24.3 & 2.42 & High & Low \\
\hline & AFGAT X PSB2005-03 & 22.4 & -2.35 & low & Low \\
\hline & WOGAYEN X PSB2005-06 & 22.3 & 1.28 & Low & Low \\
\hline \multirow{5}{*}{$\begin{array}{l}\text { Hundred seeds } \\
\text { weight } \\
\text { (g) }\end{array}$} & WOGAYEN X PSB2005-03 & 44.5 & 4.48 & Low & Low \\
\hline & BELESA 95 X PSB2005-03 & 42.0 & 2.80 & Low & High \\
\hline & GIZO X PSB2005-03 & 41.1 & -2.80 & High & High \\
\hline & GIZO X PSB2005-06 & 40.5 & 3.59 & Low & Low \\
\hline & GIZO X PSB2005-04 & 40.2 & -1.12 & Low & Low \\
\hline \multirow[t]{5}{*}{ Pod weight (g) } & ETHIOUGOSLAVIA X PSB2005-06 & 1.1 & 0.07 & Low & Low \\
\hline & BELESA 95 X PSB2005-03 & 1.1 & 0.09 & High & Low \\
\hline & WOGAYEN X PSB2005-03 & 1.0 & 0.04 & Low & Low \\
\hline & AFGAT X PSB2005-06 & 1.0 & 0.03 & Low & Low \\
\hline & WOGAYEN X PSB2005-03 & 1.0 & 0.07 & Low & Low \\
\hline \multirow{5}{*}{$\begin{array}{l}\text { Primary } \\
\text { branches }\end{array}$} & ETHIOUGOSLAVIA X PSB2005-03 & 7.3 & 1.32 & Low & Low \\
\hline & GISHAMA X PSB2005-03 & 7.3 & 0.75 & Low & Low \\
\hline & GIZO X PSB2005-04 & 7.2 & 1.18 & Low & Low \\
\hline & AFGAT X PSB2005-04 & 7.0 & 0.61 & Low & Low \\
\hline & WOGAYEN X PSB2005-04 & 6.7 & -0.34 & Low & Low \\
\hline
\end{tabular}

\section{SUMMARY AND CONCLUSION}

Two crosses Blessa95 $\times$ PSB2005-03 (high $\times$ low) and Ethiougo slavia $\times$ PSB2005-06 (low $\times$ low), exhibited high mean values for number of pods per plant and grain yield. These crosses may be further exploited for isolating the desirable segregates for economic traits of number of pods per plant and grain yield.

\section{ACKNOWLEDGEMENT}

The authors greatly thank the Ethiopian Institute of Agricultural Research for financial support. Pawe Agricultural Research Center, staff members of the Soybean Research Team is greatly acknowledged for their active and unlimited cooperation in the execution of the experiment.

\section{REFERENCES}

[1] Bastawisy, M. H.; Ibrahim, A. M. and Mansours, S. H. 1997. Combining ability and heterosis studies for yield and its components in some top crosses of soybean [Glycine Max (L.)] Merril. Annals of Agricultural Sciences, Moshtohor. 35(1): 93-106.

[2] Darwish, I. H. I. 2007. Heterosis and enheritance of some quantitative character in soybean (Glycine Max L.). Egyptean Journal of Plant Breeding. 11(1): 131-142. 
[3] El Sayad Z. S.; Seliman, M. M.; Mokhtar, S. A.; El Shaboury, H. M. G. and ElHafez, G. A. A. 2005. Heterosis, combining ability and gene action in F1 and F2 diallel crosses among six soybean. Genotypes. 43(2) : 545-559.

[4] Kampthrone, O. 1957. An introduction to genetic statistics. Johnwiley and Sons, Inc., New York. Kapila, R. K.; Gupta, V. P. and Rathore, P. K. 1994.

[5] El-Hosary, A. A., A. Gehan and N. El-Deen. 2013. Genetic analysis in the F1 and F2 soybean generations of dilllel crosses. Egypt. J. Plant Breed. 19(2): 355 -373.

[6] Raj, P. and V. S. Kandalkar. 2014. Combining ability and heterosis analysis for grain yield and its components in Soybean (Glycine max L. Merrill). Asian J. Crop Sci. 5(1): 45-49.

[7] Kumar, A. H., A. Kumar and B. Prasad. 2013. Combining ability and gene interaction study for yield, its attributing traits and quality in Soybean (Glycine max L. Merrill). J. App. Nat. Sci. 7(2): 927-934.

[8] Adel, A. A. and E. A. Ali. 2015. Gene action and combining ability in a six parent diallel cross of Soybean (Glycine max L. Merrill). Asian J. Crop Sci. 5(1): 14-23.

[9] Burungale S.V., R. M. Chauhan, R. A. Gami, D. M. Thakor and P. T. Patel. 2014. Combining ability analysis for grain and quality traits in Soybean (Glycine max L. Merrill). Trends in Bio Science, 4(1): 120-122.

[10] Istipliler, D., E. Ilker, F. A. Tonk, G. Civi and M. Tosun. 2013. Linextester analysis and estimating combining abilities for yield and some yield components in Soybean (Glycine max L. Merrill). Turk. J. Field Crops. 20(1): 72-77.

[11] Joshi, S.K., Sharma, S. N., Singhania, D. L. and R. S. Sain. 2014. Combining ability in the F1 and F2 generations of diallel cross in Soybean (Glycine $\max$ L. Merrill)). Hereditas, 141(2): 115121

Citation: T. Ghiday and Tizzazu D. "LinexTester Analysis and Estimating Combining Abilities for Yield and Some Yield Components in Soybean (Glycine max L. Merrill) ", International Journal of Research Studies in Agricultural Sciences (IJRSAS), vol. 3, no. 7, p. 5, 2017, http://dx.doi.org /10.20431 /2454-622 4.0307005 .

Copyright: (C) 2017 Authors. This is an open-access article distributed under the terms of the Creative Commons Attribution License, which permits unrestricted use, distribution, and reproduction in any medium, provided the original author and source are credited. 